\title{
APPLICATION OF RARE EARTH MAGNETS IN MINERAL PROCESSING
}

\section{I.S. WELLS}

Boxmag Rapid Ltd., Birmingham, England

and

\section{N.A. ROWSON}

University of Birmingham, Birmingham, England

(Received February 2, 1991)

\begin{abstract}
Recent advances in permanent magnet technology have led to the development of a new generation of permanent rare earth industrial magnetic separators. The excellent separation efficiency of these rare earth magnetic separators has resulted in them superceeding conventional electromagnetic high-intensity magnetic separators for many applications. One example of this technology is the Boxmag-Rapid Magnaroll magnetic separator which has been successfully installed for mineral processing applications. Research work is also presented, utilizing the Magnaroll in a novel application of removing ash and pyritic sulphur from coal samples.
\end{abstract}

\section{INTRODUCTION}

In the last two decades a revolutionary new range of permanent magnets have been developed. Known as rare earth magnets they are as much as twenty times more powerful than metal alloy or ceramic (ferrite) types available hitherto. Rare earth magnets composed of samarium and cobalt were introduced in the 1970's. More recently even more powerful permanent magnets made from neodymiumiron-boron have been developed.

Permanent magnets can be compared by reference to their energy product. From Table I it can be observed that the energy product of neodymium-iron-boron magnets is approximately ten times that of conventional ceramic types. 
The availability of rare earth magnets has enabled manufacturers of magnetic separators to exploit the very much higher magnetic field strengths to develop equipment to solve mineral beneficiation problems not previously considered possible.

TABLE I Magnetic properties of permanent magnets

\begin{tabular}{lccc}
\hline Magnet type & $\begin{array}{c}\text { Energy product } \\
\mathrm{BH}_{\max }\end{array}$ & $\begin{array}{c}\text { Remanence } \\
\mathrm{B}_{\mathrm{r}}\end{array}$ & $\begin{array}{c}\text { Coercive force } \\
\mathrm{H}_{c}\end{array}$ \\
\hline Ferrite & $3.3 \mathrm{MGOe}$ & 3700 Gauss & 3000 Oersted \\
$\begin{array}{l}\text { Samarium cobalt } \\
\text { Neodymium-iron- } \\
\text { boron }\end{array}$ & 20 & 9000 & $8250-8750$ \\
\hline
\end{tabular}

High-intensity permanent magnetic separators were developed soon after samarium-cobalt magnets became available. More recently, these separators have substituted neodymium-iron- boron magnets which are magnetically stronger and less expensive than samarium-cobalt.

\section{MAGNETIC FORCE IN A SEPARATOR}

The magnetic force exerted on a particle is given by the formulae (in cgs units)

$$
\mathrm{F}_{\mathrm{m}}=\mathrm{kVHdH} / \mathrm{dx}
$$

where $\mathbf{k}$ is the volume magnetic susceptibility of the mineral species, $\mathrm{V}$ the volume of the particle, $\mathrm{dH} / \mathrm{dx}$ the magnetic field gradient and $\mathrm{H}$ the magnetic field strength.

It can be discerned from the above relationship that for larger particles of the same mineral species, the magnetic force will be greater and therefore the probability of capture will be higher. For higher applied magnetic field field strengths, the force on the particle will also be higher. 
It must be noted that the magnetic field gradient is as important as the field strength itself. In a uniform field, a magnetically susceptible particle will not move. Consequently, in a magnetic separator it is essential to produce a magnetic field gradient. The new rare earth magnets fulfill this requirement as they produce exceptionally high field gradients with the correct magnetic field profile design.

\section{DESIGN OF HIGH-INTENSITY PERMANENT MAGNETIC SEPARATORS}

The optimum design for a high-intensity permanent magnetic separator is in the form of a magnetic head pulley constructed from rare earth magnets in the shape of discs. Figure 1 shows a diagrammatic form of a Boxmag-Rapid "Magnaroll" high-intensity permanent magnetic separator.

The magnetic head pulley forms part of a short conveyor fed at a carefully controlled rate by a vibratory feeder. The conveyor belt is of ultra-thin high-tensile strength Kevlar with antistatic surface. To maximise the available magnetic field (10 000 Gauss), the belt is no more than $0.4 \mathrm{~mm}$ thick and in some cases 0.125 mm.

The particles to be separated pass over the head pulley. The non-magnetic particles are thrown off by the centrifugal force imparted by the rotation of the pulley whilst the magnetically susceptible ones are attracted to and are held to the pulley until they pass out of the magnetic field where they are released.

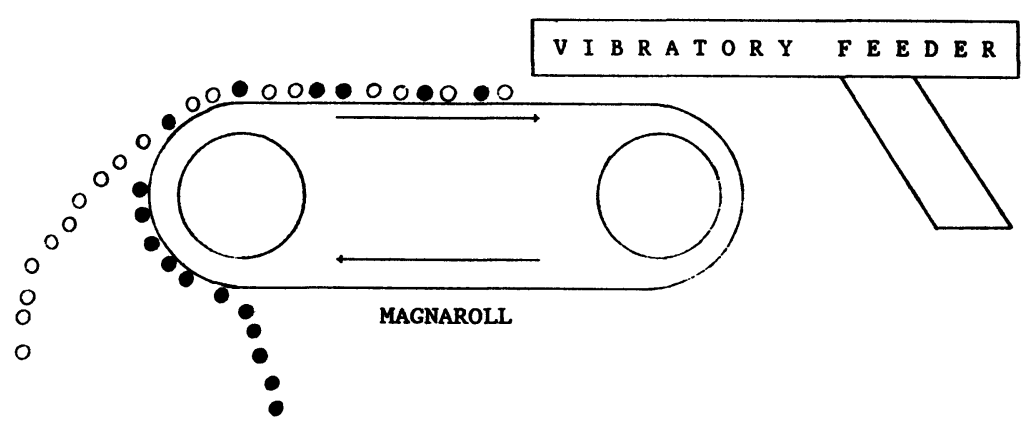

NON-MAGNETICS MAGNETICS

FIGURE 1 Operation of Magnaroll 
One of the main advantages of this style of separator is the great flexibility in the size range of feed that can be processed. By varying the diameter of the pulley and the spacing of the poles, material from $40 \mathrm{~mm}$ down to $75 \mu \mathrm{m}$ can be processed. The principal roll options are presented in Table II.

Magnarolls are available in widths up to one metre. As the belt is relatively thin, the mechanical design of the separator must ensure positive belt tracking. Magnaroll belts are manufactured with non-metallic studs incorporated along the edge which locate directly into channels in the circumference of the rolls. Furthermore, the rear (tail) pulley is crowned to eliminate the possibility of belt misalignment. Figure 2 shows a 1 metre belt width MR1.1000 Magnaroll separator.

TABLE II Roll design variations for different sized particles

\begin{tabular}{lcc}
\hline Particle size range & Roll diameter & Pole spacing \\
\hline $0-10 \mathrm{~mm}$ & $75 \mathrm{~mm}$ & narrow \\
$10-25$ & 75 & wide \\
$25-40$ & 100 & wide \\
\hline
\end{tabular}

APPLICATIONS OF HIGH-INTENSITY PERMANENT MAGNETIC SEPARATORS

High-intensity permanent magnetic separators have principally been applied for the removal of iron-bearing contaminants from dry industrial minerals. They have been typically used for extracting minerals such as limonite, ilmenite, hornblende, augite and biotite from quartz, feldspar, nepheline syenite, wollastonite, andalusite and diamonds. High-intensity permanent magnetic separators have also been successfully applied to the upgrading of bauxite and magnesite.

Outside the mineral beneficiation industry, high-intensity permanent magnetic separators are applied to the removal of iron-bearing impurities from abrasives, chemicals, calcined magnesite and bone as well as spray-dried ceramic granules. Typical mineral applications with process capacities on a MR1.1000 unit (one meter width belt) are included in Table III. 
In collaboration with the School of Chemical Engineering at the University of Birmingham, Boxmag-Rapid are investigating new applications for high-intensity permanent magnetic separators.

One promising example is the reduction of ash and sulphur contents of coal. The results of trials with high ash/high sulphur coals are presented in Table IV. It can be seen that a significant reduction in ash has been achieved in the smaller size fraction after one pass over the Magnaroll unit. Useful reductions in the sulphur content of the smaller size fraction were also achieved.

TABLE III Application of Magnaroll Magnets

Typical application

for $1 \mathrm{~m}$ wide roll

Capacity

$(\mathrm{t} / \mathrm{h})$

Removal of weakly paramagnetic

$2-3$

minerals from silica sands,

feld-spar, nepheline

Purification of spray-dried

$1-2$

ceramic granules

Upgrading of calcined bone for

$2-3$

ceramic production

Separation of serpentine from

$5-7$

magnesite

Removal of iron minerals from 


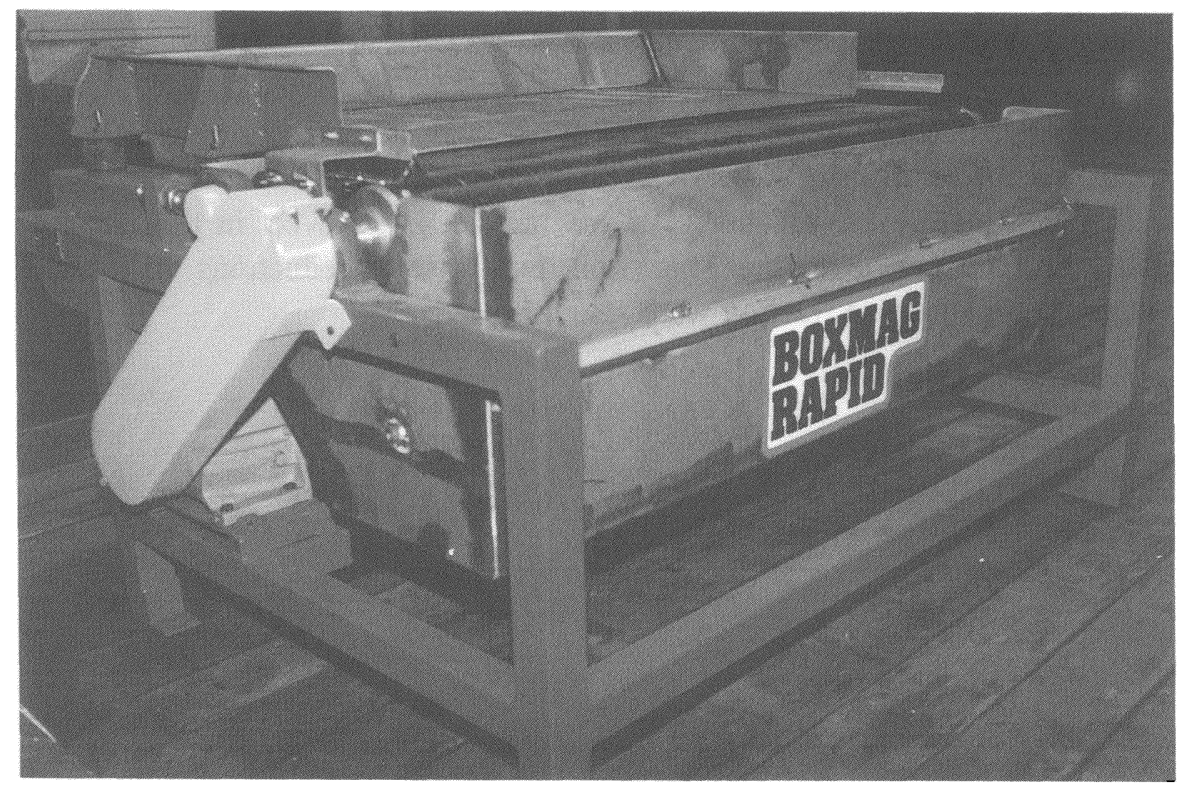

Figure 2. Boxmag Rapid MR1.1000 Magnaroll magnetic separator.

TABLE IV Results of coal cleaning utilising high-intensity permanen magnetic separator

\begin{tabular}{|c|c|c|c|c|c|c|c|c|}
\hline \multirow[b]{2}{*}{$\begin{array}{c}\text { Size Range } \\
(\mathrm{mm})\end{array}$} & \multicolumn{4}{|c|}{ Ash content (w/w)\% } & \multicolumn{4}{|c|}{ Sulphur content $(w / w) \%$} \\
\hline & $\begin{array}{l}\text { Feed } \\
\text { Coal }\end{array}$ & Mags & $\begin{array}{l}\text { Non- } \\
\text { mags }\end{array}$ & $\begin{array}{l}\text { Remo- } \\
\text { val\% }\end{array}$ & $\begin{array}{l}\text { Feed } \\
\text { Coal }\end{array}$ & Mags & $\begin{array}{l}\text { Non- } \\
\text { mags }\end{array}$ & $\begin{array}{l}\text { Remo- } \\
\text { val \% }\end{array}$ \\
\hline-1 & 10.6 & 26.0 & 5.8 & 45.3 & 3.64 & 4.98 & 3.01 & 17.3 \\
\hline$+1-1.7$ & 8.3 & 40.0 & 5.3 & 36.1 & 3.48 & 8.15 & 2.99 & 14.1 \\
\hline$+1.7-2.8$ & 08.6 & 22.0 & 6.8 & 21.3 & 3.37 & 8.44 & 3.00 & 11.0 \\
\hline$+2.8-5$ & 8.3 & 39.7 & 7.4 & 10.3 & 3.26 & 7.30 & 3.10 & 05.0 \\
\hline
\end{tabular}


Further work is now being carried out to optimise this separation with the use of multiple-pass separators and the possibility of magnetic enhancement of the pyrite by bacteria biomodification prior to processing after the Magnaroll unit.

Paper received: February 20, 1991

I.E. Wells obtained his B.Sc. (Hons) in Mineral Engineering from the University of Birmingham in 1970. For his research into electrical methods of separating minerals he was awarded a Ph.D. in 1973 also by the University of Birmingham. Since 1973 he has been employed by Boxmag-Rapid Ltd., initially as Mineral Applications Engineer; he has held his current position of sales director since 1986. Dr. Wells is an Honorary Lecturer in the School of Chemical Engineering at the University of Birmingham.

N.A. Rowson obtained his B.Sc. (Hons) in Metallurgy from Sheffield City Polytechnics and subsequently completed a Ph.D. at the University of Leeds, studying microwave radiation treatment as a means to desulphurise coal. Dr. Rawson was employed by Boxmag-Rapid Ltd. as Export Sales Manager, recently taking up an appointment as Lecturer in the School of Chemical Engineering, The University of Birmingham. Dr. Rowson is still employed by Boxmag-Rapid as marketing consultant.

Keywords: rare-earth magnets, high-intensity magnetic separation, neodymium-ironboron magnets, magnetic properties, industrial minerals, coal cleaning. 